\begin{tabular}{c} 
Volume and Issues Obtainable at Center for Sustainability Research and Consultancy \\
Responsible Education, Learning and Teaching in Emerging Economies \\
ISSN: $2708-4310$ \& (E): 2708-4183 \\
Volume 2: No.2, December 2020 \\
CSRE \\
Journal homepage: www.publishing.globalcsrc.org/relate \\
\hline
\end{tabular}

\title{
Effects of Social Media on Students at University Level during Covid-19
}

*Shabnam Bibi, Department of Education, University of Lahore, Pakistan

Muhammad Hameed Nawaz, Department of Education, University of Lahore, Pakistan

*Corresponding author's email: shabnirehman@gmail.com

ARTICLE DETAILS
History
Revised format: Nov 2020
Keylable Online: Dec 2020
Social Media, Covid-19, E-
Learning, Effects

\section{JEL Classification}

I2, I23 \begin{abstract}
Purpose: The main objective of this study was to find out the influence of social networking sites on students during COVID19 pandemic. The study was beneficial for youngster to use social media positively, informative and educational purpose and aware the youngster about the negative side of social media while they have much opportunity to stay at home and the opportunity to get education by using social media. Methodology: This research was descriptive in nature and information was collected by using the designed with an online technique. The questionnaire was prepared for measuring the different option of males and female about positive use of social media. The questionnaire covered both positive and negative effects of social media in pandemic period. The questionnaire based on five-pointlikert scale. Data was analyzed through independent t-test at SPSS. Findings: The result demonstrated that the social media has both negative and positive effects on students during COVID-19 pandemic. Students mostly use social media to get connected with friends and family and they exchanged helpful data and online classes via social media networking sites. Social media enhances social skill and developed technical skill while using it during class assignment and group discussions. Social media cause health problems and affect our cultures badly because students spend more time on social media during pandemic. Youngster spends their precious time on playing games and talking on social communication sites. Implication: This study supports the students of university level in gaining basic specific abilities and preparing them to be inhabitants in an advanced era where they can fully participate in the larger community and become familiar with social skills. This study provides information to the web based life users about the negative impacts of excessive use of internet on their mental and physical health and different risks of social networking sites contain cyber bulling.
\end{abstract}

(C) 2021 The authors, under a Creative Commons AttributionNonCommercial 4.0

Recommended citation: Bibi, S. and Nawaz, M. H. (2021). Effects of Social Media on Students at University Level during Covid-19. Responsible Education, Learning and Teaching in 
Emerging Economies, 2 (2), 49-57.

\section{Introduction}

Social media is a term used to describe the interaction between groups is people in which they create, share and sometimes exchange ideas, pictures, recordings. Young students are growing up surrounded by cell phones and interactive informal communication sites such as Twitter, MySpace, Google Chatroom, Facebook and WhatsApp which has made the social media a key part of their life. During the COVID-19 pandemic, social education has shifted from face to face to online education in order to avoid large gatherings and crowds for blocking the transmission of the virus Magidson JF, Lejuez CW, et al(2020).During COVID-19 all over the world closed their educational institute, same as in Pakistan it is advised to close their educational institute and isolate the students at their home. In Pakistan the educational institutes were closed in March 2021 this lockdown not only adversely affected the economy but also the educational activities were shut down which created a huge gap in students' learning and knowledge all over the globe Arafat SMY, Kar SK, Kabir R(2020). Students connected with their teachers, friends and family through social media and share their assignments and information through social media. Youngsters connected with each other by social media and they have used it for shopping and online learning. During the pandemic social media affected youngster positively and negatively.

UNESCO has observed that "Most governments around the world have temporarily closed educational institutions in an attempt to contain the spread of the COVID-19 pandemic. These nationwide closures are impacting over $60 \%$ of the world's student population. Several other countries have implemented localized closures impacting millions of additional learners." Overall, close to 200 countries closed their schools in the spring, thereby interrupting the education of more than 1.5 billion young people.

All schools and universities initiate share their news and positive posts effectively through social media during pandemic. This communal medium has lots of helpful effects on online learning as well as in communication, in time information, socializes online, improving ability and provides opportunity of job with others. With positive effects social media has some negative effects such as identity robbery, harassment, and societal separation.

\section{Statement of the Problem}

During COVID-19 pandemic the big challenge was how to deliver rapid, reliable information and education that need it most, at a pace equal to or better than the spreading epidemic so mostly we used social media for transferring data and information. The present study was aimed to investigate the effect of social media on students at university level during COVID-19. In recent pandemic time we used internet for learning and sharing information with friends, but mostly we use social media to share data, share assignments, online classes, group discussion and interaction between gatherings during pandemic. Now a day's social media has incredible effects on youngster. Social media has both positive and negative angles. Thus, the problem under investigation will be "effects of social media on students at university level during COVID-19"

\section{Objectives of the Study}

1. To explore the influence of social networking sites in youth.

2. To study the effects oftoo much utilization of social media on the health.

\section{Research Questions}

1. What are the positive and negative effects of social media for online learning?

2. What is the different opinion of males and females about much use of social media during COVID-19 pandemic? 


\section{Significance of the Study}

This study is very significant to understanding about the effect of social media on young generation during pandemic. Social media is a fundamental part of our society. Social media is a quickly creating platform for individuals to transmit, interact and share material of various sorts. In recent pandemic time we used internet for learning and sharing information with friends, but mostly we use social media to share data, share assignments, online classes, group discussion and interaction between gatherings. This study supports the students of university level in gaining basic specific abilities and preparing them to be inhabitants in an advanced era where they can fully participate in the larger community and become familiar with social skills. This study provides information to the web based life users about the negative impacts of excessive use of internet on their mental and physical health and different risks of social networking sites contain cyber bulling.

\section{Delimitation of the Study}

The research was delimited to:

The enrolled BS students of two public and two private sectors universities of Lahore are the population of the study. The public universities were government college university GCU Lahore and COMSATS University Islamabad, Lahore campus. The private universities were the University of Lahore and University of Central Punjab UCP.

\section{Population of the Study}

All the enrolled BS students of Govt. College University, Lahore, session 2020,2021. COMSATS university Islamabad Lahore campus session 2020, 2021. The university of Lahore session 2020, 2021. The University of Central Punjab session 2020, 2021. The population of enrolled students was 3,351 in which 2,122 were male students and 1,229 were female students.

\section{Sample}

Following departments of sampled universities were selected randomly.

I. Computer science and zoology departments of government college university GCU

II. Computer science and BBA department of the COMSATS University Islamabad, Lahore campus.

III. Education and physics departments of the University of Lahore UOL.

IV. BBA and economic department of university of central Punjab UCP.

Stratified random sampling technique was used to select the representative sample from the population. There were two strata i.e. male students and female students. Ten male and ten female students were selected by using random sampling technique of two departments of each university.

\section{Research Methodology Instrument of the Study}

The study was limited to those participants who have ease of access to android base cell phones and internet connection so the design of the study was online perspective. Medium of the questionnaire was English and link was shared to all participants who were able to understand English language and having interpreting abilities.

A questionnaire was based on five-pointlikert scale was developed for data collection. The scale values were used against each response foe example $\mathrm{SA}=$ strongly agree, $\mathrm{A}=$ agree, ND=not decided, $\mathrm{D}=$ disagree, $\mathrm{SD}=$ strongly disagree.

\section{Data Analysis}


The collected data was organized and evaluated through SPSS.

\section{Effects of Social Media during COVID-19}

In the first few months of 2020 to mid of 2021, social media was the first and most available networking site to deliver information, online learning and news reports regarding the (COVID19) and SOPs to avoid effects of coronavirus. It is much effective networking site to deliver the alerts during COVID-19 pandemic and for online learning; however social media have both negative and positive effects.

\section{Positive Effects}

1. Encourage Online Learning: Bao (2020); stated that students get encouraged and motivated to e-learn with the advance use of Social Media. Social Media has made possible on all levels of education, online notes, learning via video calling are some of the major aspects which contribute to educational development during pandemic. Social media encourage online learning during pandemic as all institutes were closed as per the order of government so students joined study groups to gain knowledge from the same while staying at home to follow social distance.

2. Improve Educational Performance: The condition to stay at house 24 hours per day and also continue the education in a dissimilar situation had the potential to impact university students' interpersonal and intrapersonal lives both educationally and socially. Social media was the first and important platform which is use for learning. Through data and information gathering on any time anywhere social media lend a hand to increase learning achievement and enhance their information. When learners are allocated with home tasks and assignments they attended online classes to gather knowledge to fill up their home tasks and assignments.

3. Improve Creative Component: Social Media lend a hand in developing one's social skills like online shopping or affairs in progress about pandemic and knowledge. Social media usage in any classroom can be a great source of education which enables to inspire students to obtain knowledge. Social Media helps in develop ingenious skills in kids by permitting them to study and afterward execute the similar by doing it themselves. Quite often a student's hidden ability is exposed when they begin to get images and utilize editing through online abilities to create it look aesthetically attractive.

\section{Unenthusiastic Impacts}

1. Causes Distraction: Social Media is major platform which is use for online learning during pandemic and it is important to distraction and hindrance of mind. During COVID19 all learners are wasting their time to enjoying different features of social media; they have lost their focus on given assignments and home tasks.

2. Impact on Physical Condition: Mao F (2020) stated that using a lot of social media apps and browsing every time on it; this carelessness has affected their physical health and also psychological condition. They are careless in taking food and rest ion time and waste their time in browsing on laptops and phones it may caused eye disease and unmotivated to learning and poor grades in education. It is advisable for parents as well as to all educational institutes to keep an eye on what their children are doing while using the internet and taking online classes. We need a sound body and mentally health to fight with corona virus we must have a strong body and strength and a fresh mind.

3. Reduces Learning and Research Capability: Owing to the development of new technology and the progress of new forms of social media, people spend more time on social media than before for getting information and connected with educational institute. Within seconds, new information, news, pictures, and videos can be posted to millions of peopleTing H, Ling J, Cheah JH (2020). The study shows that social media has an impact on learning and research capability during the COVID-19 pandemic and that social media 
posts spread panic which caused people to buy more products than needed. With the extensive use of Social Media and easy access of internet, students these days are depending more time on such platforms to gain information and knowledge rather than looking out for the same in books, journals or notes because all libraries and institutes are closed because of COVID-19. As it is easy to extract information online, reading habits of students along with their learning and research capabilities are reducing (Naeem M, (2020).

\section{Discussion}

All educational institutions, offices, recreational places, markets, import, export, transport, railways, and airlines were restricted in the country during COVID-19 to maintain the social distance and for the sake of life. In this study, to investigate the personal opinion of the students how they effected by using social media a lot as it was the major medium to connect with teachers and fellows for learning. Social media is where people interrelate each other and share ideas, images and videos. Social media involves websites for social networking like Twitter, MySpace, Facebook and WhatsApp. To talk with each other about the substance of information, and a platform for students to share their ideas, information, and thoughts social networking play a vital role. Social media incorporate websites, wikis, video- or photo-sharing sites, and other diverse platforms. At present, participating in digital media sharing and social networking is not only beneficial, but it also facilitates individual social interactions, as well as communication, by allowing users to building brands and create professional opportunities Social media has both positive and negative effect. Social media develop technical and social skills. It is very helpful for doing assignments and class notes. Helpful data and material can be exchange on social networking sites. Social media provides opportunity to fine out jobs or earning.

On the negative side, many youngsters waste their time in playing games and chatting on social networking sites. It is very harmful for mental and physical health. Internet is loaded with risks associated with online communities like Cyber bulling and cybercrime. Mostly female participants reported that students are relying increasingly on information and data that is easily accessible on social networking sites and the internet. This is the reason why students' learning skills and research capabilities are decreasing in certain situations, as their engagement with these sites reduces their focus, which causes them to dedicate less time to their studies and results in a decline in their academic performance. Mostly participants reported that typically, as students spend more time on social media, they spend less time socializing face to face or in person with other people, and these habits reduce their communication skills. Normally thy use social media 4 to 5 hours daily but in Covid-19 pandemic they use social media 15 to 16 hours per day as they were restricted at home because of corona virus pandemic.

\section{Achievements}

This study were designed with an online perspective, and limited to those participants having accessibility to android base cell phones and internet connection. The mode of this questionnaire was English; therefore, the link was sent to those participants who were able to understand English, with thinking and interpreting abilities, willing to respond to the designed questionnaire. In this study 160 students were participated. 160 responses were includedand responded were $100 \%$. Male and female both respond $100 \%$ and agreed that social media help then during COVID-19 pandemic in their learning but it has affected positively and negatively. Mostly females $70 \%$ were agreed that social media affected negatively and wasted their precious time in playing games, online shopping, gossip, and social sharing. Only 30\% Male students were agreed Social media affected their ability and wasted the time in different activities but it help them to keep busy at home as it was requested by government of Pakistan to stay at home and isolate them 24 hours per day. 
Social networks enable to remain connected with family and friends during pandemic

\begin{tabular}{lllllllllll}
\hline Responses & $\begin{array}{l}\text { Strongly } \\
\text { agree }\end{array}$ & Agree & $\begin{array}{l}\text { Not } \\
\text { decided }\end{array}$ & Disagree & $\begin{array}{l}\text { Strongly } \\
\text { disagree }\end{array}$ & $\mathbf{N}$ & $\mathbf{M}(\mathbf{S D})$ & $\mathbf{D F}$ & $\begin{array}{l}\text { T } \\
\text { Value }\end{array}$ & $\begin{array}{l}\text { Sig } \\
\text { tailed) }\end{array}$ \\
\hline Male & 44 & 29 & 5 & 0 & 2 & 80 & $1.59(.822)$ & 158 & -.209 & .835 \\
Female & 38 & 37 & 3 & 2 & 0 & 80 & $1.61(.684)$ & & & \\
\hline
\end{tabular}

$\mathrm{p}>0.05$

The table 1.1 shows that the mean score 1.59 of male was less that the female mean score 1.61 and the value of SD .822 of male was greater than the SD .684 of female. Independent t-test was applied in which $\mathrm{p}$ value .835 was greater than 0.005 . Hence the high mean score shows that the majority of females were agreed with this statement.

Useful information can be exchanged over social networking sites during pandemic

\begin{tabular}{lllllllllll}
\hline Responses & $\begin{array}{l}\text { Strongly } \\
\text { agree }\end{array}$ & Agree & $\begin{array}{l}\text { Not } \\
\text { decided }\end{array}$ & Disagree & $\begin{array}{l}\text { Strongly } \\
\text { disagree }\end{array}$ & N & M(SD) & DF & $\begin{array}{l}\text { T } \\
\text { Value }\end{array}$ & $\begin{array}{l}\text { Sig } \\
\text { tailed) }\end{array}$ \\
\hline Male & 28 & 45 & 5 & 1 & 1 & 80 & $1.78(.729)$ & 158 & .233 & .816 \\
Female & 28 & 44 & 8 & 0 & 0 & 80 & $1.75(.626)$ & & & \\
\hline
\end{tabular}

$\mathrm{p}>0.05$

The table 1.2 shows that the mean score 1.78 of male was greater than the female mean score 1.75 and the value of SD .729 of male was greater than the SD .626 of female. Independent t-test was applied in which $\mathrm{p}$ value .816 was greater than 0.005 . Hence the high mean score shows that the majority of males were agreed with this statement.

Social media has increased cyber bulling during COVID-19

\begin{tabular}{lllllllllll}
\hline Responses & $\begin{array}{l}\text { Strongly } \\
\text { agree }\end{array}$ & Agree & $\begin{array}{l}\text { Not } \\
\text { decided }\end{array}$ & Disagree & $\begin{array}{l}\text { Strongly } \\
\text { disagree }\end{array}$ & N & M(SD) & DF & $\begin{array}{l}\text { T } \\
\text { Value }\end{array}$ & $\begin{array}{l}\text { Sig } \\
\text { tailed) }\end{array}$ \\
\hline Male & 23 & 33 & 19 & 3 & 2 & 80 & $2.10(.949)$ & 158 & -.337 & .737 \\
Female & 20 & 36 & 17 & 6 & 1 & 80 & $2.15(.929)$ & & & \\
\hline
\end{tabular}

$$
\mathrm{p}>0.05
$$

The table 1.3 shows that the mean score 2.10 of male was less than the female mean score 2.15and the value of SD .949 of male was greater than the SD .929 of female. Independent t-test was applied in which $\mathrm{p}$ value .737 was greater than 0.005 . Hence the high mean score shows that the majority of females were agreed with this statement.

Using social networks are posing negative effects on your studies by any means during pandemic 2020-2021

\begin{tabular}{lllllllllll}
\hline Responses & $\begin{array}{l}\text { Strongly } \\
\text { agree }\end{array}$ & Agree & $\begin{array}{l}\text { Not } \\
\text { decided }\end{array}$ & disagree & $\begin{array}{l}\text { Strongly } \\
\text { disagree }\end{array}$ & N & M(SD) & DF & $\begin{array}{l}\text { T } \\
\text { Value }\end{array}$ & $\begin{array}{l}\text { Sig } \\
\text { tailed) }\end{array}$ \\
\hline Male & 12 & 40 & 15 & 9 & 4 & 80 & $2.41(1.040)$ & 158 & -.337 & .737 \\
Female & 22 & 42 & 6 & 7 & 3 & 80 & $2.15(1.021)$ & & & \\
\hline
\end{tabular}

$\mathrm{p}>0.05$

The table 1.4 shows that the mean score 2.41 of male was greater than the female mean score 2.09 and the value of SD 1.040 of male was greater than the SD 1.021 of female. Independent ttest was applied in which $p$ value .048 was less than 0.005 . Hence the high mean score shows that the majority of males were agreed with this statement.

The use of internet for doing assignments and enriching class notes during pandemic 2020-2021

\begin{tabular}{lllllllllll}
\hline Responses & $\begin{array}{l}\text { Strongly } \\
\text { agree }\end{array}$ & Agree & $\begin{array}{l}\text { Not } \\
\text { decided }\end{array}$ & disagree & $\begin{array}{l}\text { Strongly } \\
\text { disagree }\end{array}$ & N & M(SD) & DF & $\begin{array}{l}\text { T } \\
\text { Value }\end{array}$ & $\begin{array}{l}\text { Sig } \\
\text { tailed) }\end{array}$ \\
\hline Male & 30 & 29 & 17 & 4 & 0 & 80 & $1.94(.891)$ & 158 & .654 & .514 \\
Female & 39 & 24 & 10 & 5 & 2 & 80 & $1.84(1.037)$ & & & \\
\hline
\end{tabular}

$\mathrm{p}>0.05$

The table 1.5 shows that the mean score 1.94 of male was greater than the female mean score 1.84 and the value of SD .891 of male was less than the SD 1.037 of female. Independent t-test was applied in which $\mathrm{p}$ value .514 was greater than 0.005 . Hence the high mean score shows that the majority of males were agreed with this statement. 
You used social media 4-5 hours daily only for study purposes

\begin{tabular}{lllllllllll}
\hline Responses & $\begin{array}{l}\text { Strongly } \\
\text { agree }\end{array}$ & Agree & $\begin{array}{l}\text { Not } \\
\text { decided }\end{array}$ & disagree & $\begin{array}{l}\text { Strongly } \\
\text { disagree }\end{array}$ & $\mathbf{N}$ & M(SD) & DF & $\begin{array}{l}\text { T } \\
\text { Value }\end{array}$ & $\begin{array}{l}\text { Sig } \\
\text { tailed) }\end{array}$ \\
\hline Male & 42 & 20 & 15 & 1 & 2 & 80 & $1.76(.971)$ & 158 & -.335 & .738 \\
Female & 35 & 31 & 9 & 4 & 1 & 80 & $1.81(.915)$ & & & \\
\hline
\end{tabular}

$\mathrm{p}>0.05$

The above table 1.6 shows that the mean score 1.76 of male was less than the female mean score 1.81 and the value of SD .971 of male was greater than the SD .915 of female. Independent t-test was applied in which $\mathrm{p}$ value .738 was greater than 0.005 . Hence the high mean score shows that the majority of females were agreed with this statement.

Many young people wasting a lot of their time on playing games and chatting through social networks during

\begin{tabular}{lllllllllll} 
Responses & $\begin{array}{l}\text { Strongly } \\
\text { agree }\end{array}$ & Agree & $\begin{array}{l}\text { Not } \\
\text { decided }\end{array}$ & disagree & $\begin{array}{l}\text { Strongly } \\
\text { disagree }\end{array}$ & N & M(SD) & DF & $\begin{array}{l}\text { T } \\
\text { Value }\end{array}$ & $\begin{array}{l}\text { Sig } \\
\text { tailed) }\end{array}$ \\
\hline Male & 31 & 41 & 6 & 1 & 1 & 80 & $1.75(.755)$ & 158 & -.335 & .738 \\
Female & 40 & 30 & 8 & 0 & 2 & 80 & $1.68(.854)$ & & & \\
\hline
\end{tabular}

$\mathrm{p}>0.05$

The table 1.7 shows that the mean score 1.75 of male was greater than the female mean score 1.68 and the value of SD .755 of male was less than the SD .854 of female. Independent t-test was applied in which $\mathrm{p}$ value .557 was greater than 0.005 . Hence the high mean score shows that the majority of males were agreed with this statement.

Social media provides means of e-learning during pandemic

\begin{tabular}{lllllllllll}
\hline Responses & $\begin{array}{l}\text { Strongly } \\
\text { agree }\end{array}$ & Agree & $\begin{array}{l}\text { Not } \\
\text { decided }\end{array}$ & disagree & $\begin{array}{l}\text { Strongly } \\
\text { disagree }\end{array}$ & N & M(SD) & DF & $\begin{array}{l}\text { T } \\
\text { Value }\end{array}$ & $\begin{array}{l}\text { Sig } \\
\text { tailed) }\end{array}$ \\
\hline Male & 26 & 34 & 18 & 2 & 0 & 80 & $1.95(.810)$ & 158 & .534 & .594 \\
Female & 33 & 32 & 8 & 6 & 1 & 80 & $1.88(.960)$ & & & \\
\hline
\end{tabular}
$\mathrm{p}>0.05$

The table 1.8 shows that the mean score 1.95 of male was greater than the female mean score 1.88 and the value of SD .810 of male was less than the SD .960 of female. Independent t-test was applied in which $\mathrm{p}$ value .594 was greater than 0.005 . Hence the high mean score shows that the majority of males were agreed with this statement.

Too use much use of social media causes mental and physical problem

\begin{tabular}{lllllllllll}
\hline Responses & $\begin{array}{l}\text { Strongly } \\
\text { agree }\end{array}$ & Agree & $\begin{array}{l}\text { Not } \\
\text { decided }\end{array}$ & disagree & $\begin{array}{l}\text { Strongly } \\
\text { disagree }\end{array}$ & N & M(SD) & DF & $\begin{array}{l}\text { T } \\
\text { Value }\end{array}$ & $\begin{array}{l}\text { Sig } \\
\text { tailed) }\end{array}$ \\
\hline Male & 26 & 28 & 19 & 7 & 0 & 80 & $2.09(.957)$ & 158 & .704 & .482 \\
Female & 21 & 45 & 9 & 4 & 1 & 80 & $1.99(.834)$ & & & \\
\hline
\end{tabular}

$\mathrm{p}>0.05$

The table 1.9 shows that the mean score 2.09 of male was greater than the female mean score 1.99 and the value of SD .957 of male was greater than the SD .834 of female. Independent t-test was applied in which $\mathrm{p}$ value .482 was greater than 0.005 . Hence the high mean score shows that the majority of males were agreed with this statement.

Social media provides opportunity to find online jobs or earning during pandemic

\begin{tabular}{lllllllllll}
\hline Responses & $\begin{array}{l}\text { Strongly } \\
\text { agree }\end{array}$ & Agree & $\begin{array}{l}\text { Not } \\
\text { decided }\end{array}$ & disagree & $\begin{array}{l}\text { Strongly } \\
\text { disagree }\end{array}$ & N & M(SD) & DF & $\begin{array}{l}\text { T } \\
\text { Value }\end{array}$ & $\begin{array}{l}\text { Sig } \\
\text { tailed) }\end{array}$ \\
\hline Male & 22 & 34 & 20 & 3 & 1 & 80 & $2.09(.889)$ & 158 & -.425 & .671 \\
Female & 19 & 41 & 11 & 7 & 2 & 80 & $1.15(.969)$ & & & \\
\hline
\end{tabular}

$\mathrm{p}>0.05$

The table 1.10 shows that the mean score 2.09 of male was less than the female mean score 2.15 and the value of SD .889 of male was less than the SD .969 of female. Independent t-test was applied in which $\mathrm{p}$ value .671 was greater than 0.005 . Hence the high mean score shows that the majority of females were agreed with this statement. 
Social media is useful for online shopping and advertisement during COVID-19

\begin{tabular}{lllllllllll}
\hline Responses & $\begin{array}{l}\text { Strongly } \\
\text { agree }\end{array}$ & Agree & $\begin{array}{l}\text { Not } \\
\text { decided }\end{array}$ & disagree & $\begin{array}{l}\text { Strongly } \\
\text { disagree }\end{array}$ & N & M(SD) & DF & $\begin{array}{l}\text { T } \\
\text { Value }\end{array}$ & $\begin{array}{l}\text { Sig } \\
\text { tailed) }\end{array}$ \\
\hline Male & 25 & 36 & 15 & 4 & 0 & 80 & $1.98(.842)$ & 158 & -.176 & .861 \\
Female & 27 & 33 & 15 & 3 & 2 & 80 & $2.00(.955)$ & & & \\
\hline
\end{tabular}

$\mathrm{p}>0.05$

The table 1.11 shows that the mean score 1.98 of male was less than the female mean score 2.00 and the value of SD .842 of male was less than the SD .955 of female. Independent t-test was applied in which $\mathrm{p}$ value .861 was greater than 0.005 . Hence the high mean score shows that the majority of females were agreed with this statement.

Social media has positive impact on youth during online classes

\begin{tabular}{lllllllllll}
\hline Responses & $\begin{array}{l}\text { Strongly } \\
\text { agree }\end{array}$ & Agree & $\begin{array}{l}\text { Not } \\
\text { decided }\end{array}$ & disagree & $\begin{array}{l}\text { Strongly } \\
\text { disagree }\end{array}$ & N & M(SD) & DF & $\begin{array}{l}\text { T } \\
\text { Value }\end{array}$ & $\begin{array}{l}\text { Sig } \\
\text { tailed) }\end{array}$ \\
\hline Male & 6 & 24 & 29 & 12 & 9 & 80 & $2.93(1.100)$ & 158 & 3.370 & .001 \\
Female & 16 & 33 & 18 & 12 & 1 & 80 & $2.36(1.009)$ & & & \\
\hline
\end{tabular}

$\mathrm{p}>0.05$

The table 1.12 shows that the mean score 2.93 of male was greater than the female mean score 2.36 and the value of SD 1.100 of male was greater than the SD 1.009 of female. Independent ttest was applied in which $\mathrm{p}$ value .001 was less than 0.005 . Hence the high mean score shows that the majority of males were agreed with this statement.

Social media is helpful to create awareness among youth during pandemic

\begin{tabular}{lllllllllll}
\hline Responses & $\begin{array}{l}\text { Strongly } \\
\text { agree }\end{array}$ & Agree & $\begin{array}{l}\text { Not } \\
\text { decided }\end{array}$ & disagree & $\begin{array}{l}\text { Strongly } \\
\text { disagree }\end{array}$ & N & M(SD) & DF & $\begin{array}{l}\text { T } \\
\text { Value }\end{array}$ & $\begin{array}{l}\text { Sig } \\
\text { tailed) }\end{array}$ \\
\hline Male & 17 & 35 & 20 & 4 & 4 & 80 & $2.29(1.021)$ & 158 & .151 & .880 \\
Female & 21 & 31 & 17 & 8 & 3 & 80 & $2.26(1.076)$ & & & \\
\hline
\end{tabular}

$\mathrm{p}>0.05$

The table 1.13 shows that the mean score 2.29 of male was greater than the female mean score 2.26 and the value of SD 1.021 of male was less than the SD 1.076 of female. Independent t-test was applied in which $p$ value .880 was greater than 0.005 . Hence the high mean score shows that the majority of males were agreed with this statement.

Social media groomed your social skills during online practices

\begin{tabular}{lllllllllll}
\hline Responses & $\begin{array}{l}\text { Strongly } \\
\text { agree }\end{array}$ & Agree & $\begin{array}{l}\text { Not } \\
\text { decided }\end{array}$ & disagree & $\begin{array}{l}\text { Strongly } \\
\text { disagree }\end{array}$ & N & M(SD) & DF & $\begin{array}{l}\text { T } \\
\text { Value }\end{array}$ & $\begin{array}{l}\text { Sig } \\
\text { tailed) }\end{array}$ \\
\hline Male & 36 & 25 & 15 & 3 & 1 & 80 & $1.85(.943)$ & 158 & 1.883 & .062 \\
Female & 41 & 32 & 5 & 2 & 0 & 80 & $2.26(.722)$ & & & \\
\hline
\end{tabular}

$\mathrm{p}>0.05$

The table 1.14 shows that the mean score 1.85 of male was greater than the female mean score 1.60 and the value of SD .943 of male was greater than the SD .722 of female. Independent t-test was applied in which $p$ value .062 was greater than 0.005 . Hence the high mean score shows that the majority of males were agreed with this statement.

Unwanted information creates confusion in the mind of youth during pandemic

\begin{tabular}{lllllllllll}
\hline Responses & $\begin{array}{l}\text { Strongly } \\
\text { agree }\end{array}$ & Agree & $\begin{array}{l}\text { Not } \\
\text { decided }\end{array}$ & disagree & $\begin{array}{l}\text { Strongly } \\
\text { disagree }\end{array}$ & N & M(SD) & DF & $\begin{array}{l}\text { T } \\
\text { Value }\end{array}$ & $\begin{array}{l}\text { Sig } \\
\text { tailed) }\end{array}$ \\
\hline Male & 18 & 36 & 14 & 10 & 2 & 80 & $2.28(1.031)$ & 158 & 1.076 & .284 \\
Female & 22 & 40 & 10 & 4 & 4 & 80 & $2.10(1.026)$ & & & \\
\hline
\end{tabular}

$\mathrm{p}>0.05$

The table 1.15 shows that the mean score 2.28 of male was greater than the female mean score 2.10 and the value of SD 1.031 of male was greater than the SD 1.026 of female. Independent ttest was applied in which p value .284 was greater than 0.005 . Hence the high mean score shows that the majority of males were agreed with this statement. 


\section{References}

Arafat SMY, Kar SK, Menon V, Kaliamoorthy C, Mukherjee S, Alradie-Mohamed A, et al. Panic buying: an insight from the content analysis of media reports during COVID-19 pandemic. Neurol Psychiatry Brain Res. (2020) 37:100-3. doi: 10.1016/j.npbr.2020.07.002

Islam T, Pitafi H, Wang Y, Aryaa V, Mubarik S, Akhater N, et al. Panic buying in the COVID19 pandemic: a multi-country examination. J Retail Consum Serv. (2020) 59:102357. doi: 10.1016/j.jretconser.2020.102357

Yuen KF, Wang X, Ma F, Li KX. The psychological causes of panic buying following a health crisis. Int J Environ Res. (2020) 17:3513. doi: 10.3390/ijerph17103513

Arafat SMY, Kar SK, Menon V, Alradie-Mohamed A, Mukherjee S, Kaliamoorthy C, et al. Responsible factors of panic buying: an observation from online media reports. Front Public Health. (2020) 8:603894. doi: 10.3389/fpubh.2020.603894

Arafat SMY, Kar SK, Marthoenis M, Sharma P, Hoque Apu E, Kabir R. Psychological underpinning of panic buying during pandemic (COVID-19). Psychiatry Res. (2020) 289:113061. doi: 10.1016/j.psychres.2020.113061

Mao F. Coronavirus Panic: Why are People Stockpiling Toilet Paper? (2020). Available online at: https://www.bbc.co.uk/news/world-australia-51731422 (accessed December 03, 2020]

Ting H, Ling J, Cheah JH. It Will Go Away!? Pandemic crisis and business in Asia. Asian J Bus Res. (2020) 10:I-VII. doi: 10.14707/ajbr.200072

Magidson JF, Lejuez CW, Kamal T, Blevins EJ, Murray LK, Bass JK, et al. Adaptation of community health worker-delivered behavioral activation for torture survivors in Kurdistan, Iraq. Glob Ment Health. (2015) 2:e24. doi: 10.1017/gmh.2015.22

Arafat SMY, Kar SK, Kabir R. Possible controlling measures of panic buying during COVID19. Int J Ment Heal Addict. (2020):1-3. doi: 10.1007/s11469-020-00320-1. [Epub ahead of print].

Arafat SMY, Kar SK, Menon V, Marthoenis M, Sharma P, Alradie-Mohamed A, et al. Media portrayal of panic buying: a content analysis of online news portals. Glob Psychiatry. (2020) 3:249-54. doi: 10.2478/gp-2020-0022

Ahmad AR, Murad HR. The impact of social media on panic during the COVID-19 pandemic in Iraqi Kurdistan: online questionnaire study. J Med Internet Res. (2020) 22:19556. doi: $10.2196 / 19556$

Naeem M. Do social media platforms develop consumer panic buying during the fear of Covid19 pandemic. J Retail Consum Serv. (2021) 58:102226. doi:

10.1016/j.jretconser.2020.102226 